Article

\title{
SUSTAINABLE DEVELOPMENT IN BRAZIL: A CONGLOMERATED ANALYSIS FOR FEDERATIVE UNITS
}

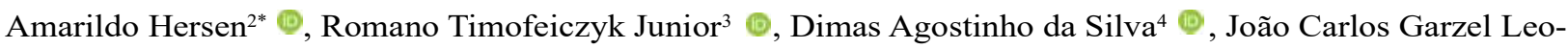 \\ doro Da Silva ${ }^{4}$, and Jandir Ferrera de Lima ${ }^{5}$
}

\footnotetext{
${ }^{1}$ Received on 13.09.2018 accepted for publication on 16.10.2019.

${ }^{2}$ Universidade Estadual do Centro-Oeste, Departamento de Economia, Guarapuava,PR- Brasil. E-mail: <amarildohersen@yahoo.com.br>.

${ }^{3}$ Universidade Federal do Paraná, Departamento de Economia Rural e Extensão,Curitiba,PR- Brasil. E-mail: <romano.timo@gmail.com>.

${ }^{4}$ Universidade Federal do Paraná, Departamento de Engenharia e Tecnologia Florestal,Curitiba,PR- Brasil. E-mail: <dimas.agostinho. silva@gmail.com> and < garzelufpr@gmail.com>.

${ }^{5}$ Universidade Estadual do Oeste do Paraná, Departamento de Economia,Toledo,PR- Brasil. E-mail: <jandirbr@yahoo.ca>.

*Corresponding author.
}

\begin{abstract}
This paper develops and analyzes a taxonomy that divides the Federative Units of Brazil into groups with similar characteristics, distributed over the indicators of the four dimensions of sustainable development described by the Dashboard of Sustainability method. The research methodology adopted was multivariate analysis by interdependence technique through cluster analysis. The results suggest that on average, the federal units contribute differently to the different dimensions of sustainable development of the country and form distinct groups. Brazil's sustainable development index has an environmental dimension with a strong contribution from the grouping of states in the North and Northeast regions. The social dimension is positively influenced by the grouping composed of the federative units of the South and Midwest regions. In contrast, the economic dimension is positively influenced by all federal units, however, in a different way. The institutional dimension was mainly influenced by Ceará and Bahia (Northeast region), all South and Southeast states and the Federal District, Mato Grosso and Mato Grosso do Sul (Center-West region), all components of a single grouping.
\end{abstract}

Keywords: Sustainability indicator; Brazilian territory; Regional Inequality.

\section{DESENVOLVIMENTO SUSTENTÁVEL NO BRASIL: UMA ANÁLISE DE CONGLOMERADOS PARA AS UNIDADES FEDERATIVAS}

RESUMO - Esse artigo desenvolve e analisa uma taxonomia que particione as Unidades Federativas do Brasil em grupos com características similares, distribuidas sobre os indicadores das quatro dimensões do desenvolvimento sustentável descritas pelo método Dashboard of Sustainability. A metodologia de pesquisa adotada foi a análise multivariada por técnica de interdependência através da análise de conglomerados. Os resultados sugerem que, em média, as unidades federativas contribuem de forma diferenciada para as diferentes dimensões do desenvolvimento sustentável do país e formam grupos distintos. O índice de desenvolvimento sustentável do Brasil tem a dimensão ambiental com forte contribuição do agrupamento formado pelos Estados das regiões Norte e Nordeste. A dimensão social é positivamente influenciada pelo agrupamento composto pelas unidades federativas das regiões Sul e Centro-Oeste. Diferentemente, a dimensão econômica é influenciada positivamente por todas as unidades federativas, contudo, de maneira diferenciada. A dimensão institucional mostrou-se influenciada principalmente por Ceará e Bahia (região Nordeste), todos os estados do Sul e Sudeste e Distrito Federal, Mato Grosso e Mato Grosso do Sul (região Centro-Oeste), todos componentes de um único agrupamento.

Palavras-Chave: Indicador de sustentabilidade; Território brasileiro; Desigualdade regional. 


\section{INTRODUCTION}

The notion of sustainable development has its origin in the international debate about the concept of development. This is actually the history of the revaluation of the concept of development predominantly on the growth idea for a broader notion, which includes environmental and social factors creating the concept of sustainable development (Bellen, 2006).

The need for the broader notion came from the impact produced by the Club of Rome, which in the 1970 s commissioned studies related to the profile of world development. Among the results of these studies, in 1972 came the report "Limits of Growth". The report stated that the fundamental problems facing society stemmed from maintaining unlimited economic growth in the face of a planet with finite natural resources. As a result, exponential growth in consumption and population would lead to depletion of natural resources, increasing levels of pollution and scarcity in the near future (Meadowset al., 1973).

The term sustainable development was first discussed by the International Union for the Conservation of Nature and Natural Resources (IUCN), in the document entitled World's conservation strategy (IUCN, 1980). In this, for development to be understood as sustainable, it must consider aspects related to social and ecological dimensions and economic factors, living and non-living resources and the short and long-term advantages of alternative actions. The focus of the concept was on environmental integrity, but with the Brundtland Report, the emphasis is on the human element, thus generating a balance between the economic, environmental and social dimensions (Bellen, 2006).

Because it is a continuous and complex process, there are numerous approaches that seek to explain the concept of sustainable development - such as the work of Bossel (1998); Costanza (1991); Hardi and Zdan (1997); Pronk and Ul Haq (1992); Rutherford (1997); Wackenagel and Rees (1996); Word Bank (1995); among others.

Despite the diversity of definitions of the term sustainable development, according to Bellen (2006), the two most well-known and cited definitions are that of the Brundtland Report prepared from the World
Commission on Environment and Development (WCED, 1987) and that of the document known as the Agenda 21 (UN, 1992). For both documents cited, sustainable development is one that meets present needs without compromising the ability of future generations to meet their own needs.

The concept of sustainability can be better understood from several dimensions. Considering sustainability as a dynamic concept that encompasses a process of change, the concept also presents evolution of the classical dimensions, also identified under five dimensions: social, economic, ecological, territorial and cultural. Countries must develop from their own strengths to implement an endogenous development strategy without neglecting their insertion into the global economy given the dimensions of sustainability (Dahl, 1997; Ferrera de Lima, 2018; Sachs, 2008).

In order to measure sustainable development and synthesize its magnitude, there is a need to develop sustainable development indicators. This need is expressed even in Agenda 21 itself (UN, 1992), with predefined goals and deadlines for the development of appropriate tools for decision makers, whether public or private managers. IBGE (2015) points out that the presentation of sustainable development indicators must follow the ordering framework proposed by the UN Commission on Sustainable Development (CSD), which organizes them into four dimensions: environmental, social, economic and institutional.

Based on the above, the objective of the research was to identify and analyze the groupings of the federative units of Brazil for the different dimensions of sustainable development, using the framework of the sustainable development estimation method called Dashboard of Sustainability.

\section{MATERIAL AND METHOD}

\subsection{Selection of sustainability indicator structure}

When comparing internationally recognized sustainability assessment tools, Bellen (2006) consulted experts in the field and suggested some indicators. Although there is no unanimity, among methodologies not listed by the returning experts and others not listed, but cited by them, the three most remembered indicator systems account for $35.4 \%$ of the indications. The evaluation methodologies

Revista Árvore 2019;43(6):e430604 
that obtained the most indications in the survey were: Ecological Footprint Model - EFM (13.92\%), Dashboard of Sustainability - DS (12.66\%) and Barometer of Sustainability - BS (8.86\%).

The EFM methodology has the purpose of determining the area required for a given system to be maintained, becoming a function of the material and energy consumption of a population. It presents as limitations its static character, not allowing extrapolations in time, only provides information to sensitize society. The system does not include several important issues, which are often directly related to land use, such as lost areas of biological productivity due to contamination, erosion and urban use. Because the method considers only the economic effects of resource-use decisions and simplifies the calculation methodology, its results lead to more optimistic perspectives than actually occur (Hardi and Barg, 1997).

On the other hand, the DS methodology, or Sustainability Panel, aggregates several indicators within "dials" and from the calculation of these indices the final result of each "dial" is obtained. An additional function averages these dials so that a Sustainable Development Index, SDI can be reached. The Sustainability Panel was developed by the Consultative Group on Sustainable Development Indicators (CGSDI) and is based on the United Nations Commission for Sustainable Development (CSD) set of indicators, currently containing 19 social, 20 environmental, 14 economic and 8 institutional indicators (IISD, 2017). For Bellen (2006), the instrument allows for a quick assessment of a nation's strengths and weaknesses, allowing for comparison with other countries and although more consistent and transparent in its form and presentation than most other existing indexes, more improved versions should be developed.

The Barometer of Sustainability (BS) offers the use of performance scales for combining different indicators. The scale ranges from good or great, to bad or very bad. The underlying hypothesis is that sustainable development is a combination of human well-being and the ecosystem. Information is organized into two subsystems - human and ecosystem - each divided into five dimensions. The dimension indices are considered of equal importance and aggregated by subsystems, which generate the general index when combined (Siena, 2008). BS only seeks to measure the most representative aspects of the system through indicators (Prescott-Allen, 1999). Regarding the criticism received by this indicator, they are focused on the performance scale, considered by many as subjective (Bellen, 2006).

Given the above, this research makes use of the sustainability indicator framework called Dashboard of Sustainability (DS), as it is one of the most recognized and accepted by experts in the field, to estimate sustainable development. The instrument is suitable for promoting comparisons between different territories and identifying their strengths and weaknesses, purposes associated with the objective of this research. The indicators that make up the Dashboard of Sustainability are detailed in IISD (2016). The representative elements of each indicator used in the research are described below (Table1).

It is noteworthy that the indicators whose relationship was negative suffered inversion to adherence to the method proposed below. It was decided to use a positive or direct relationship between the indicators, thus an increase in the indicator's magnitude results in the improvement of the system and to make all indicators express the understanding of the bigger the better, the inversion of the indicators whose relationship was negative followed the proposition of Sepúlveda (2005):

$$
f(x)=(x-M) /(m-M)
$$

Where $\mathrm{x}=$ corresponding value of the variable or indicator for a given unit of analysis over a period of time; $\mathrm{M}=$ is the maximum level in a given period; $\mathrm{m}$ $=$ is the minimum level in a given period.

Once evidenced the set of elements of the indicators used in this research, the next step was to detail the analysis method performed, that is, the cluster analysis.

\subsection{Analysis method}

Cluster analysis classifies objects - respondents, products, entities, etc. — so that each object resembles the others in the cluster, based on a set of characteristics chosen, being homogeneous within the cluster and heterogeneous across clusters (Hair Jr. et al., 2009). 
Table 1 - Elements of sustainability indicators by dimension $(2012 * *)$.

Tabela 1 - Elementos dos indicadores de sustentabilidade por dimensão (2012**).

\begin{tabular}{|c|c|c|c|c|}
\hline Dimension & Cod. & Representative element of the indicator & Ref. Year & Source \\
\hline \multirow{12}{*}{$\begin{array}{l}\text { Environmental } \\
\quad 1\end{array}$} & A01* & $\mathrm{CO} 2$ emission (ton) & 2012 & Climate Observatory \\
\hline & $\mathrm{A} 02 *$ & Emission of other GHG CH4 $+\mathrm{N} 2 \mathrm{O}$ emission (ton) & 2012 & Climate Observatory \\
\hline & A04* & Urban air pollution $-\mathrm{NOx}+\mathrm{CO}$ (ton) emission & 2012 & Climate Observatory \\
\hline & $\mathrm{A} 05^{*}$ & Planted area of main crops (ha) & 2012 & IBGE \\
\hline & A06* & Fertilizer use per unit area $(\mathrm{kg} / \mathrm{ha})$ & 2012 & IBGE \\
\hline & $\mathrm{A} 07^{*}$ & Marketing of pesticides and the like, planted area $(\mathrm{kg} / \mathrm{ha})$ & 2012 & IBGE \\
\hline & A08 & $\begin{array}{l}\text { Forest Area (Remaining area of Atlantic Forest, Pampas, } \\
\text { cerrado, caatinga, wetland and legal Amazon }+ \text { area of } \\
\text { planted pine and eucalyptus forest in } \mathrm{km}^{2} \text { ) }\end{array}$ & $2009 / 10 / 12$ & IBGE/SFB \\
\hline & $\mathrm{A} 10^{*}$ & Area susceptible to desertification $(\%)$ & 2012 & CGEE \\
\hline & A $11 *$ & $\begin{array}{l}\text { Permanent private housing units unsuitable for } \\
\text { home (\%) }\end{array}$ & 2012 & IBGE \\
\hline & A13* & Resident population in coastal area & 2010 & IBGE \\
\hline & A19 & Conservation Unit, proportion in relation to State area (\%) & 2013 & IBGE/MMA \\
\hline & $\mathrm{A} 20$ & $\begin{array}{l}\text { Bird Species/Species of mammals prorated by the } \\
\text { proportion of area remaining of the biome (s) within the } \\
\text { State territory }\end{array}$ & $2006 / 2012$ & $\begin{array}{l}\text { Avebase/Reis et al } \\
\text { (2006) }\end{array}$ \\
\hline \multirow{15}{*}{ Social } & S01* & $\begin{array}{l}\text { Households with a monthly per capita income of less than } 1 / 2 \\
\text { minimum wage }(\%)\end{array}$ & 2012 & IBGE \\
\hline & $\mathrm{S} 02 *$ & Gini coefficient & 2012 & IPEA \\
\hline & S03* & Unemployment rate $(\%)$ & 2012 & IBGE \\
\hline & S04 & $\begin{array}{l}\text { Average monthly income ratio } 15 \text { year olds } \\
\text { or older }(\mathrm{F} / \mathrm{M})\end{array}$ & 2012 & IBGE \\
\hline & S06* & Infant mortality rate (per 1000 live births) & 2012 & IBGE \\
\hline & S07 & Life expectancy at birth & 2012 & IBGE \\
\hline & S08 & $\begin{array}{l}\text { Permanent private housing units, suitable for } \\
\text { housing, with sewage system or septic tank (\%) }\end{array}$ & 2012 & IBGE \\
\hline & S09 & $\begin{array}{l}\text { Permanent private housing units, suitable for } \\
\text { housing, with general water supply }(\%)\end{array}$ & 2012 & IBGE \\
\hline & $\mathrm{S} 10$ & Health facilities per 1,000 inhabitants & 2012 & IBGE \\
\hline & $\mathrm{S} 12 *$ & Fertility rate & 2012 & IBGE \\
\hline & $\mathrm{S} 14$ & $\%$ of 18 to 20 year olds with completed high school & 2010 & PNUD \\
\hline & $\mathrm{S} 15$ & People literacy - 15 years and over $(\%)$ & 2012 & IBGE \\
\hline & S17* & Coefficient of homicide mortality (per 100 thousand inhabitants) & 2011 & MS \\
\hline & S18* & Geometric average annual population growth rate $(\%)$ & $2000 / 2010$ & IBGE \\
\hline & S19* & Demographic density (hab/km2) & 2010 & IBGE \\
\hline \multirow{10}{*}{ Economic } & E01 & $\begin{array}{l}\text { Nominal per capita household annual income of the } \\
\text { resident population }(\mathrm{R} \$)\end{array}$ & 2014 & IBGE \\
\hline & E03 & Balance Trade balance (US\$ 1,000) & 2013 & SECEX \\
\hline & E04* & $\begin{array}{l}\text { Public debt with the National Treasury and the } \\
\text { National Financial System (R\$) }\end{array}$ & 2012 & BACEN \\
\hline & E07* & Commercial Energy Consumption (gwh) & 2012 & MME \\
\hline & E08 & Renewable Energy Generation (gwh) & 2012 & MME \\
\hline & E09* & Energy efficiency (energy consumption mwh/GDP in R\$) & 2012 & ANATEL/IPEA \\
\hline & E10 & Municipalities with selective waste collection service (\%) & 2008 & IBGE \\
\hline & E11* & Number of radioactive installations (Units) & 2010 & MME \\
\hline & E13 & Waste properly disposed of in relation to total (\%) & 2008 & IBGE \\
\hline & E14* & Car fleet (units) & 2012 & DENATRAN \\
\hline \multirow{2}{*}{-} & I01 & $\begin{array}{l}\text { (\%) Cities with active Environment Council } \\
\text { (held meeting in the last } 12 \text { months) }\end{array}$ & 2012 & IBGE \\
\hline & I02 & (\%) Cities participating in River Basin & 2012 & IBGE \\
\hline
\end{tabular}

Revista Árvore 2019;43(6):e430604 
Table 1 - Elements of sustainability indicators by dimension (2012**).

\begin{tabular}{|c|c|c|c|c|}
\hline \multicolumn{5}{|c|}{ Tabela 1 - Elementos dos indicadores de sustentabilidade por dimensão (2012**). } \\
\hline & I03 & Internet user 10 years of age and over (every 1,000 inhabitants) & 2012 & IBGE \\
\hline & I04 & Telephone lines $($ fixed + mobile) & 2012 & ANATEL \\
\hline & I05 & Expenditure on science and technology $(\mathrm{R} \$)$ & 2010 & IPEA \\
\hline
\end{tabular}

Source: multiple sources, according to last column of the table.

Note: $(*)$ Indicator in need of inversion. $(* *)$ According to column three, most elements refer to the year 2012, in the absence the nearest year was sought.

Fonte: múltiplas fontes, conforme última coluna da tabela.

Nota: (*) Indicador com necessidade de inversão. (**) Conforme coluna três, a maioria dos elementos se refere ao ano de 2012, na ausência se buscou o ano mais próximo.

The objects grouped in this paper were the Brazilian states - twenty-six states, one federal district - and the characteristics of groupings were based on the 61 sustainability indicators of the sustainability panel.

To mitigate the eventual occurrence of multicollinearity, considering that the elements used in the analysis contain strong theoretical support, the procedure adopted was to reduce the subjects (States) to equal numbers in each set, as suggested by Hair Jr. et al. (2009). There was no case elimination to correct eventual existence of outliers, because it was sought, in the words of Hair Jr. et al. (2009, p.431) "(...) ensure that strong conceptual support precedes the application of the technique".

The use of variables with different scales or measures may distort the structure of the grouping, since the variable with the largest dispersion has the highest weight in the calculation of the distance measurement, compared to the other variables. This problem was solved by standardizing the variables. Hair Jr. et al (2009) point out that the most widespread way to standardize data is to transform each variable into a standard score ( $\mathrm{Z}$ score). The $\mathrm{Z}$ score method standardizes each variable $(x)$ to present zero average and standard deviation 1 , as follows:

$$
z=\frac{(x-\bar{x})}{\sigma}
$$

Where $\mathrm{x}$ is a standard variable and $\sigma$ is the standard deviation of variable $\mathrm{x}$.

The identification of groups of subjects or variables becomes possible only by adopting some measure of similarity that allows objective comparison between the subjects. In cluster analysis, observations are grouped by some kind of distance metric. Thus, the next step was to define the measure of similarity or dissimilarity (distance) to be used. Considering that the data used in this research are classified as metric, we used the "Squared Euclidean distance (SED)" as a distance measure. For Fávero et al. (2009) is the appropriate distance criterion for group formation in the Ward hierarchical method and is given by:

$$
d_{i j}^{2}=\sum_{k=1}^{p}\left(x_{i k}-x_{j k}\right)^{2}
$$

Where $x_{i k}$ is the value of the $k$ variable for $i$ observation and $x_{j k}$ represents the $k$ variable for $j$ observation.

After the procedure of calculating the distances between the observations, the results demand the elaboration of similarity matrix between the observations. With ownership of the matrix, the next step is to determine the algorithm that will make the grouping process, that is, specify the aggregation method chosen. The most commonly used clustering algorithms are hierarchical and nonhierarchical. Hierarchical solutions are preferred when all alternative solutions should be examined and when sample size is moderate - over 300, not exceeding 1,000 (Hair Jr. et al., 2009).

In the Ward method, similarity between two clusters is not a single measure of similarity, but the sum of squared clusters made over all variables. The Ward method consists of a) Calculate the means of the variables for each group; b) Calculate the square of the Euclidean distance between these means and the values of the variables for each individual; c) The distances are summed for all individuals; d) Minimizes variance within groups - the objective function to be minimized is called sum of error squares (Fáveroet al., 2009).

Because the method works with squared values, it is consequently more sensitive to the magnitude of the observations. This reason, added to the fact that it 
is a sample classified as moderate size, contributed to the definition of the selected grouping method.

Finally, to determine the number of clusters there is no single criterion. Percentage variations in heterogeneity is the most widespread rule, as the Ward clustering method observes the sum of squares within the cluster. Therefore, the percentage increase in the clustering coefficient is calculated for each solution. Then cluster solutions are selected as the potential final solution when the percentage increase is considerably greater than in other steps (Hair Jr. et al., 2009). As it is necessary to employ several stopping rules and seek a consensus solution, it was also decided to define the number of clusters based on the graphical visualization of the dendrogram and use of the twostep method. Moreover, the detailed analysis of the characteristics (data) of each state was crucial for the final definition of the groupings.

Fávero et al. (2009) suggest that the validation be performed using different similarity measures, seeking to evaluate the consistency of the results. In addition, it is up to the researcher to carefully analyze the generated groupings and, having the characteristics of the objects or study elements, perform the relevant interpretations.

The groupings found will be exposed with the symbols (+), (-) and $( \pm)$. The symbol used is suggestive and, in order to go beyond the differentiation of groups, it highlights the group more, less and moderately contributing, respectively, to the dimension of sustainable development.

\section{RESULTS}

In cluster analysis, it is important to note that the fact to identify the belonging of some states to the same group do not characterized as similar in every respect. This is because the analysis takes into account the set of variables for grouping definition and not specifically one variable or characteristic.

Also, despite the perception of observations with characteristics very different from the others (outliers), no observation exclusion procedure was performed because it is understood that Brazil, a country of continental dimensions, has a territory with environmental, social, heterogeneous and often even conflicting economic and institutional factors, as evidenced by the works of Ribeiro (2015), Chein et al. (2007), Domingues and Ruiz (2006), Madeira (2014), among others.

Table 2 shows the distribution of federative units grouped by their characteristics in each dimension of sustainable development, making it possible to identify the most and least contributory groups by size of the index.

The applied technique allowed the interpretation of two groupings for the environmental, social and institutional dimension. In the economic dimension, at first glance it seemed that the formation of two groups would be appropriate, a suggestion even perceived by the twostep method. However, with a more critical analysis, it was found that there would be no possibility of segregating these two groups as the most contributory and the least contributory because both had very positive points, while presenting extremely negative points about the economic dimension of sustainability.

Moreover, except for São Paulo, all states would form a single group. The solution found was the aggregation of all states into a single group, and for the purpose of analysis, the division into three subgroups with visible strengths and weaknesses peculiar to each subgroup. Statistically, this proved to be the most suitable alternative, whereas it does not generate clashing groups, contributing positively to mitigate any effect due to multicollinearity. Although São Paulo continues to represent a single group, the three groupings created enabled important interpretations.

In order to synthesize the groupings of Brazilian states in the different dimensions of sustainable development, we sought to illustrate (Figure 1) this allocation in the form of a Venn diagram.

Of the twenty-seven federative units, only four (Espírito Santo, Rio de Janeiro, Santa Catarina and the Federal District) contribute most significantly to all dimensions of sustainable development, and most shows are more contributory in only two dimensions.

\section{DISCUSSION}

Regarding the environmental dimension, on average, the northern and northeastern states of Brazil are the ones that emit the least pollutant gases $(\mathrm{CO} 2$, 
Table 2 - Brazil: Taxonomy of Brazilian federative units distributed on the dimensions of sustainable development described by the Dashboard of Sustainability (DS) method, $2012 *$

Tabela 2 - Brasil: Taxonomia das UFs brasileiras distribuida sobre as dimensões do desenvolvimento sustentável descritas pelo método Dashboard of Sustainability (DS), 2012*

\begin{tabular}{|c|c|c|c|c|c|}
\hline \multirow[t]{2}{*}{ Great Regions } & \multirow[t]{2}{*}{ Federation Units } & \multicolumn{4}{|c|}{ Dimension } \\
\hline & & $\mathrm{A}$ & $\mathrm{S}$ & $\mathrm{E}$ & $\mathrm{T}$ \\
\hline \multirow{7}{*}{ North } & Rondônia & + & - & $\pm^{*}$ & - \\
\hline & Acre & + & - & $\pm *$ & - \\
\hline & Amazonas & + & - & $\pm *$ & - \\
\hline & Roraima & + & - & $\pm *$ & - \\
\hline & Pará & + & - & $\pm *$ & - \\
\hline & Amapá & + & - & $\pm *$ & - \\
\hline & Tocantins & + & - & $\pm *$ & - \\
\hline \multirow{9}{*}{ Northeast } & Maranhão & + & $\overline{-}$ & $\pm^{*}$ & - \\
\hline & Piauí & + & - & $\pm *$ & - \\
\hline & Ceará & + & - & $\pm *$ & + \\
\hline & Rio Grande do Norte & + & - & $\pm *$ & - \\
\hline & Paraíba & + & - & $\pm *$ & - \\
\hline & Pernambuco & + & - & $\pm *$ & - \\
\hline & Alagoas & + & - & $\pm *$ & - \\
\hline & Sergipe & + & - & $\pm *$ & - \\
\hline & Bahia & - & - & $\pm *$ & + \\
\hline \multirow{4}{*}{ Southeast } & Minas Gerais & - & + & $\pm^{* *}$ & + \\
\hline & Espírito Santo & + & + & $\pm * *$ & + \\
\hline & Rio de Janeiro & + & + & $\pm * *$ & + \\
\hline & São Paulo & - & + & $\pm * * *$ & + \\
\hline \multirow{3}{*}{ South } & Paraná & - & + & $\pm^{* *}$ & $\overline{+}$ \\
\hline & Santa Catarina & + & + & $\pm * *$ & + \\
\hline & Rio Grande do Sul & - & + & $\pm * *$ & + \\
\hline \multirow{3}{*}{ Center-West } & Mato Grosso do Sul & - & + & $\pm^{*}$ & + \\
\hline & Mato Grosso & - & + & $\pm^{*}$ & - \\
\hline & Goiás & - & + & $\pm *$ & + \\
\hline
\end{tabular}

Note: A = Environmental Dimension; S = Social Dimension; E = Economic Dimension; I = Institutional Dimension. $\left({ }^{*}\right)$ For reference year see Table 1

Source: research data.

Nota: $A$ = Dimensão ambiental; $S=$ Dimensão social; $E$ = Dimensão econômica; I = Dimensão institucional. (*) Sobre o ano de referência ver Tabela 1.

Fonte: Dados da pesquisa.

$\mathrm{CH} 4$ and $\mathrm{N} 2 \mathrm{O}$, NOx and $\mathrm{CO}$ ), a result related to forest cover (North), low industrialization and extensive livestock profile. Among these, the highlight as the lowest issuer is the state of Amapá. This positive average profile of the North and Northeast States contributed to classify them as strongly contributing to the environmental dimension of Brazilian sustainable development. In the Southeast region, only the states of Espírito Santo and Rio de Janeiro stood out positively in the environmental dimension. The highlight of the State of Rio de Janeiro was mainly due to the relative small amount of agricultural area and, consequently, the use of fertilizers and pesticides. In the South region, Santa Catarina stood out and in the CenterWest, the Federal District. This feature made this set of states the first grouping of the environmental dimension.
The second grouping of the environmental dimension is constituted from the perspective of agricultural area and the use of pesticides and pesticides. The states of Bahia, Minas Gerais, Sao Paulo, Paraná, Rio Grande do Sul, Mato Grosso and Mato Grosso do Sul are the main agricultural producers, pesticide and pesticide applicators in the country, thus contributing to a lower expressiveness of these States in the environmental dimension. The state of Bahia, not different from most of the northeastern states of Brazil, faces the aggravation of having part of its territory as an area susceptible to the process of desertification and expansion of the semi-arid, contributing to its lesser expression in the environmental dimension of the country. From the perspective of the number of conservation areas and fauna diversity, the northern states of Brazil again 
Source: research data.

Fonte: Dados da pesquisa.

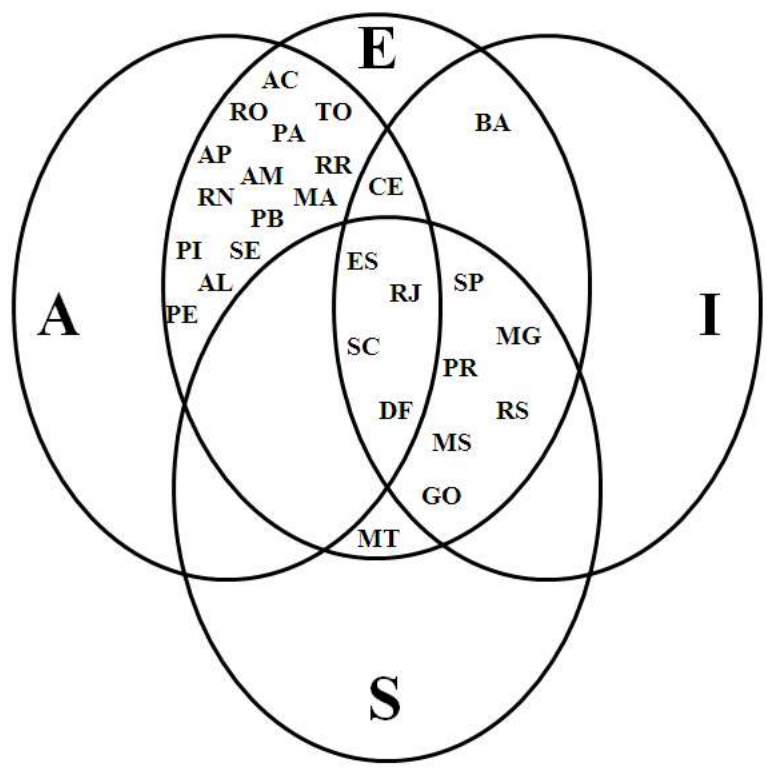

Figure 1 - Major contributions of Brazilian federative units to the dimensions of sustainable development.

Figura 1 - Principais contribuições das UFs brasileiras para as dimensões do desenvolvimento sustentável

take advantage and stand out in the indicators related to this theme in the environmental dimension.

Regarding the social dimension of the sustainable development indicator, regional differences have widened. There are clearly two distinct clusters: the first cluster, composed of states in the North and Northeast, are characterized, on average, by a higher percentage of low-income households, higher income concentration, higher unemployment rates, higher infant mortality rates and lower life expectancy at birth. The most critical situation in the Northeast is attributed to Maranhão, according to the state with the highest percentage of households with per capita income below half the minimum wage, second only to Alagoas, and holder of the highest income concentration in Brazil. The worst performance regarding life expectancy at birth and infant mortality can also be attributed to the state of Maranhão.

In the northern region of Brazil, the states of Acre, Amazonas and Amapá have the most difficulty in contributing more significantly to the social dimension of sustainable development in the country. The high percentage of households with per capita income below half the minimum wage, the high infant mortality rate, the lack of adequate housing with sewage system, the high fertility rate, the low education level and the significant population growth rates are major difficulties and obstacles to improving the social dimension of sustainable development in the region.

In contrast, in the Southeast, South and CenterWest regions, there are the largest contributions of the social dimension of sustainable development in the country. Although many advances are possible, all federative units in these regions have come together to make the most relevant contributions to the dimension. The state of Santa Catarina deserves special mention for having a lower percentage of households with per capita income below half the minimum wage, lower income concentration, and lower income inequality by gender, lower infant mortality rate and higher life expectancy at birth, lower fertility rate and higher literacy rate of youth and adults throughout Brazil. The other federative units, to a greater or lesser degree, are closer to Santa Catarina's performance.

Unlike the previous dimensions, the economic dimension was full of peculiarities. Despite understood as a single grouping, to interpret it was decided to divide it into three subgroups. The first subgroup, denoted with the symbol $\left( \pm^{*}\right)$ in Table 2 , consists of federative units with the lowest public debt, lower commercial energy consumption, fewer radioactive facilities (nuclear medicine, sealedsource device industries, and others).The biggest highlight is Amapá, which has no unit and Rondônia, Acre and Roraima, which have only one radioactive installation unit - the smallest vehicle fleets are in this cluster. However, this grouping is also characterized, on average, by lower generation of energy from renewable sources, the worst rates of selective waste collection and proper disposal of waste among the three groupings of the economic dimension.

The biggest highlight is Amapá, which has no unit and Rondônia, Acre and Roraima, which have only one radioactive installation unit - the smallest vehicle fleets are in this cluster. However, this grouping is also characterized, on average, by lower

Revista Árvore 2019;43(6):e430604 
generation of energy from renewable sources, the worst rates of selective waste collection and proper disposal of waste among the three groupings of the economic dimension.

The third and last subgroup of the economic dimension, denoted as $( \pm * * *)$, consisted exclusively of the State of São Paulo. Although the state of São Paulo has the second highest per capita household income in Brazil, is one of the largest generators of energy from renewable sources and one of the states that stands out in the proper disposal of waste, it presents serious difficulties in other indicators. São Paulo has the largest trade déficit, the largest public debt, the largest commercial energy consumption, the largest number of radioactive installations and the largest vehicle fleet among all federative units in the country. Thus, while this state stands out positively in one set of indicators, it is also extremely weak in others. Precisely because the state of São Paulo presented positive prominence in the indicators in which the first subgroup presented a déficit, it was decided to analyze it separately. In addition, as it usually presents extreme indicators, in other words, sometimes the best and sometimes the worst indicator, it did not maintain the intermediate profile to be part of the second dimension subgroup.

Regarding the institutional dimension, except for the states of Ceará and Bahia, the North and Northeast States were less contributive to the sustainable development of the country and together with the state of Mato Grosso formed the first of the two groupings of the dimension. In this group, the states of Piauí and Paraíba had the lowest percentage of municipalities with an active Environment Council, making up only $9 \%$ of the total municipalities. The state of Pará has only $6 \%$ of its cities participating in river basin committees. The state of Maranhão also has the smallest number of internet users among all the federative units of Brazil. The average grouping presents the lowest access by the population to telephone lines. Finally, the clustering, on average, showed the states with the lowest expenditures on science and technology in the country.

Conversely, the second grouping of the institutional dimension consists, on average, of federative units with the best indicators. The group includes the states of Southeast and South, the states of Ceará and Bahia and in Center-West, the Mato
Grosso do Sul, Goiás and the Federal District. In addition to the medium-high performance profile of the great majority of federative units in all dimension indicators, São Paulo and Distrito Federal take turns leading them.

After cluster analysis, which consequently encourages comparisons, the possibility of a greater contribution that most federative units can make to improve the sustainable development of the country is clear, especially when it is observed that only $14.81 \%$ stand out in the four dimensions of the index and most reach prominence in only two dimensions.

\section{CONCLUSION}

The Federative Units of the Brazilian territory showed different intensities and ways of contributing to the national index of sustainable development, a fact perceived by the existence of more than one grouping by dimension of sustainable development. In terms of environment, two clusters were found. The most contributive grouping showed, on average, lower emission of polluting gases and/or small relative amount of agricultural area and consequently of the use of fertilizers and pesticides. However, this does not mean that certain federative units do not face serious problems related to deforestation and burnings.

For the social dimension, two different groupings were also identified. The federative units of the Southeast, South and Center-West regions formed the most prominent grouping and presented the largest contributions of the social dimension of sustainable development in the country. For the economic dimension, the solution found was the elaboration of a single cluster, analyzed from the perspective of three subgroups with strengths and weaknesses peculiar to each subgroup. Only the state of São Paulo was isolated in a single group, explained by its great economic expressiveness for the country.

Finally, the institutional dimension presented two clusters: the first cluster formed by apparent déficit in the dimension is constituted by the North and Northeast States (except the states of Ceará and Bahia) and Mato Grosso. Part of the first grouping of the Piauí and Paraíba dimension (with a small number of municipalities with an active Environmental Council), the State of Pará (only 
$6 \%$ of its municipalities participate in river basin committees) and the State of Maranhão (State with the smallest number of internet users in all of Brazil). The grouping on average presented the lowest access by the population to telephone lines and aggregates the states with the lowest spending on science and technology in the country. The second grouping of the dimension was composed, on average, by federative units with the best indicators. The group includes the states of Southeast and South, the states of Ceará and Bahia and Center-West the Mato Grosso do Sul, Goiás and the Federal District. São Paulo and the Federal District take turns leading the best indicators for the institutional dimension.

The results suggest that there is no integrated action between federative units in order to jointly contributing more effectively to a given dimension of sustainable development of the country, since it was not difficult to notice neighboring federative units, from the same region, participating in different groups, often conflicting.

It is suggested the integration of actions between federative units, through public policies, working groups and interstate agreements, with a view to effective, orchestrated, holistic sustainable development, with specialized teams and goals to be achieved, for sustainable development resulting from planned actions and not by chance of other government priorities.

The main advantage of this research was that no federative unit was excluded from the analysis, providing a complete measurement of the Brazilian territory. The biggest difficulty, which turned out to be a disadvantage, was to find all indicators by state, as they are generally only available in aggregate form for the country as a whole, which led to a slight increase in the margin of error and decreased sample confidence (number of indicators represented).

The methodology applied in the present research proved to be contributive to better understand the issue of sustainable development in the country, from the perspective of spatiality. Complementary studies, with different spatial cut-outs, or even for control, monitoring and planning at the regional and state levels, and territory management, would positively aggregate in the pursuit of improving sustainable development in Brazil.

\section{REFERENCES}

Bellen HMV. Indicadores de sustentabilidade: uma análise corporativa. $2^{\mathrm{a}}$.ed. Rio de Janeiro: FGV; 2006. v.2

Bossel H. Earth at a crossroads: paths a sustainable future. Cambridge: Cambridge University Press; 1998.

Chein F, Lemos MB, Assunção JJ. Desenvolvimento desigual: evidências para o Brasil. Revista Brasileira de Economia. 2007; 61(3): 301-30.

Costanza R. Ecological economics: the science and management of sustainability. New York: Columbia University Press; 1991.

Dahl AL. The big picture: comprehensive approaches. In: Moldan B, Billharz S, editors. Sustainability indicators: report of the project on indicators of sustainable development. Chichester: John Wiley \& Sons; 1997.

Domingues EP, Ruiz RM. Os desafios ao desenvolvimento regional brasileiro. Ciência e Cultura. 2006; 58: 42-4.

Favero LP, Belfiore P, Da Silva FL, Chan BL. Análise de dados: modelagem multivariada para tomada de decisões. Rio de Janeiro: Elsevier; 2009.

Ferrera De Lima J. Política de desenvolvimento sustentável. In: Serpe B, Silva L, organizadores. Desenvolvimento, gênero e pobreza. Ponta Grossa: EdUEPG; 2018. p. 17-36.

Hardi P, Zdan TJ. Assessing sustainable development: principles and practice. Winnipeg: IISD; 1997.

Hardi P, Barg S. Measuring sustainable development: review of current practice. Winnipeg: IISD; 1997.

Hair Jr JF, Black WC, Babin BJ, Anderson RE, Tatham RL. Análise multivariada de dados. $6^{\mathrm{a}}$.ed. Porto Alegre: Bookman; 2009.

Instituto Brasileiro de Geografia e Estatística IBGE. Indicadores de desenvolvimento sustentável: Brasil 2015. Rio de Janeiro: IBGE; 2015.

International Institute for Sustainable Development - IISD. New software allows people to measure

\section{Revista Árvore 2019;43(6):e430604}


sustainability. 2002. [acessado: 20 jan. 2017]

Disponível: http://www.iisd.org/media/new-softwareallows-people-measure-sustainability.

International Institute for Sustainable Development - IISD. Compendium: a global directory to indicator iniciatives. 2004. [acessado: $23 \mathrm{dez}$. 2016] Disponível: http://www.iisd.org/measure/ compendium.

International Union for Conservation of Nature and Natural Resources - IUCN. World conservation strategy: living resource conservation for sustainable development. Gland, Switzerland and Nairobi, Kenya: IUCN/UNEP/WWF; 1980.

Madeira WV. Plano Amazônia sustentável e desenvolvimento desigual. Ambiente \& Sociedade. 2014; 17(3): 19-34.

Meadows DH, Meadows DL, Randers J, Behrens III WW. Limites do crescimento: um relatório para o projeto do Clube de Roma sobre o dilema da humanidade. São Paulo: Perspectiva; 1973.

Prescott-Allen R. Assessing progress toward sustainability: the system assessment meted illustrated by the wellbeing of nations. Cambridge: IUCN; 1999.

Pronk J, Ul Haq M. Sustainable development: from concept to action - the Hague report. New York: United Nations Development Programme; 1992.

Ribeiro MG. Território e desigualdades de renda em regiões metropolitanas do Brasil. DADOS - Revista de Ciências Sociais. 2015; 58(4): 913-49.

Rutherford ID. Use of models to link indicators of sustainable development. In: Moldan B, Billharz $\mathrm{S}$, editors. Sustainability indicators: a report on the project on indicators of sustainable development. Chichester: John Wiley and Sons; 1997.

Sachs I. Desenvolvimento: includente, sustentável, sustentado. Rio de Janeiro: Garamond; 2008.

Sepúlveda S. Desenvolvimento microrregional sustentável: métodos para planejamento local. Brasília: IICA; 2005.

Siena O. Método para avaliar desenvolvimento sustentável: técnicas para escolha e ponderação de aspectos e dimensões. Produção. 2008; 18 (2); 359-74.

United Nations - UN. Agenda 21. United Nations Conference on Environment \& Development. 1992. [acessado: 15 jan. 2017] Disponível: https:// sustainable development.un.org/content/documents/ Agenda21.pdf.

Wackernagel M, Rees W. Our ecological footprint: reducing human impact on the earth. Gabriola Island, BC e Philadelphia, PA: New Society; 1996.

World Commission on Environment and Development - WCED. Our common future. Oxford and New York: Oxford University Press; 1987.

World Bank. Monitoring environmental progress: a report on work in progress. Washington, DC, USA: The World Bank; 1995. 